\title{
The role of art colonies in local development through the example of Cered Art Colony
}

\author{
Zoltán Bujdosó ${ }^{1}$, Béla Benkő ${ }^{1}$, Csaba Patkós ${ }^{2}$ \\ ${ }^{1}$ Szent Istvan University Károly Róbert Campus, 3200 Gyöngyös, Mátrai út 36. Hungary; ${ }^{2}$ Eszterhazy Karoly University Eger, Hungary \\ E-mail addresses: Bujdoso.Zoltan@szie.hu, Benko-Bela@szie.hu, patkos.csaba@uni-eszterhazy.hu
}

\begin{abstract}
The current study's topic is the summary of the roles of art colonies in the local example. The theoretical basis of the study was given by the international scientific literature of art colonies and the role of culture in the life of settlements. The matter of research is relevant as an investigation based on a case study has not been made yet on this topic; moreover, it consists of important results for the professionals. On this basis, it can be determined that which factors affect positively the human and natural environment through an art colony. A further advantage of the study can conclude to the possible development ways of culture in the life of villages. The current research, regarding the future, is an ideal starting point to know the role of art in local (and regional) development. The main results of the case study are the tangible effects of the colony on the (natural and human) environment.
\end{abstract}

Keywords - art colony, culture, local development, Cered, Hungarian-Slovakian border region

\section{INTRODUCTION}

Spatial and settlement development is a consciously reasoned and continuous intervention into the economic, environmental, social and built-up elements of a given settlement or region. Although basically it is a task of the state, nowadays it more and more becomes a multi-actor activity. (Madanipour et al 2014) Beyond agents of central and local executive power (state and municipalities) private (enterprises and natural persons) and non-profit organizations play an ever relevant role formally and informally too (Klamár et al, 2019). Recently spatial development can't function without public participation as it may secure the mobilization of inner resources (Matyas, 2015). Art can be interpreted as an activity helping to raise senses and to resurface hidden capabilities. (Ingold 2013) The surrounding environment is of great importance in this process (Csíkszentmihályi 1999)

An art colony is a more or less organized formation assuring time, space and community for artists to create and might provide opportunities for outsiders to learn too. (Mattingly 2019) Though it seems to be a pointwise from a geographic point of view, at the same time through arts and connected artists it may be an integral part of a broader regional or global network as well. Art can't be separated from the surrounding socio-economic background (Becker 1982), art colonies and their geographic neighbourhoods are in a tight interaction. This connectivity is tried to be used by the rural development policy consciously in job creation, tourism and local business development (Bujdoso, 2004; Bujdoso et al, 2015, Gkartzios and Crawshaw 2019).

The key actor of the process is undisputedly the artist who can form society through the diffusion of culture, overcome barriers (it might be named the creation of new ideas, fashionably speaking innovation) or creation of identity (Gaztambide-Fernández 2008).

The spatial development role of artists and arts was examined by many scholars (Zukin 1989; Rosenfeld 2004, Markusen 2007), but their function is considered relevant mainly in case of bigger cities, as a critical mass can presumably be reached there. A post-modern city is creative according to the popular epithet. Key words as creative industry, city and class (Florida 2002) respectively milieu (Meusburger 2009) are determining phrases among professionals, politicians and even among ordinary people. The creative environment - used by Törnqvist (1983) - is related to the networks and connections of well-educated 
people, being mostly implicit and non-formal. Even in Slovenia, where the majority of settlements is small and less-concentrated, artists are concentrated to the biggest towns (Kozina and Bole 2017).

This medium is not only part of the image and culture of a given settlement, but is an integrated element of the local society and economy as supporting economic growth, tourism and the boost of employment. As their products are frequently sold outside the region they may be reckoned a quasi export-oriented branch (Markusen 2006, 2014). Additionally, they can inspire the different segments of the creative industry, like IT. (Landry 2008) As a consequence, additional economic activities settle down using the opportunities given by arts.

Arts as integrated part of the creative industry have a multiplicative economy effect (Bille and Schulze 2011). In that respect inhabitants, enterprises, trade and the civil society are affected. At the same time the individual artist is in the centre.

Artist - people owing some overflow from some kind of cultural capital (Bourdieu 1984) - beyond economic-cultural value given form special demands regarding culture, recreation and housing as inhabitants and consumers (Jeffri 1988, Ilies et al. 2020). The consequences of their activities transform the environment of the settlement to a great extent. For example, in the rural areas of Northern England the activities of the local art colony were used to reveal local housing challenges, additionally artistic solution ideas were created as well (Gkartzios and Crawshaw 2019).

The special behavior and activities of artists create particular spaces inside the settlements, places of dwelling, quarters of culture or even art colonies (Brennan-Horley 2010).

Creativity is conventionally thought to be the character of urbanized regions, as these may provide frequent interactions to support networks. Nowadays creative environments are associated with rural, less-inhabited and generally more natural areas as well (McGranahan and Wojan 2007).

Beyers-Lindahl (1996) have argued decades ago that the members of the creative class like the countryside, because of the near the nature milieu, cheaper prices and the spread of electronic communication. Accordingly, creativity is present not only in the - admittedly spectacular - downtown artist quarters, but in other parts of the settlement as well. (Debroux 2013) A flourishing commuter activity of artists can be seen between urban nodes and peripheral rural settlements (Działek and Murzyn-Kupisz 2014).

In rural development arts as part of creative economy play triple role. Through the utilization of local built, material and intangible cultural heritage economy is diversified (Komives and Kiraly, 2019). Additionally, culture-based economic activities can be created in craftwork, design and music. This might help in retaining the youth in rural backward regions. The third form is to get closer to the local community through literature, poetry and performing activities. (Woods 2012)

Accordingly, the connection of cultural and art activities to local communities is a crucial question. In the creation of art colonies the central power (state) can have a decisive role with making political decisions and assigning resources to the creation of them. On the other hand colonies can be created by a spontaneous bottom-up process as well. In the second case there is a higher chance to integrate the local community and create an organic connection between the colony and local people (Liang and Wang 2020).

Art colonies are integrated parts, very often decisive points of the spatial structure of the different regions. For example, in Bosnia-Hercegovina the village of Pocitelj, with less than 1000 inhabitants is the home of a colony of global importance with its historic milieu restored after the Balkan War (Pickard and Dambis 2008). Art also can be a brand of a settlements (Matlovicova et al, 2019).

Lazic in her study in 2017 analyzed art colonies situated in the rural zones of Serbia. She argued that many such establishments were created during the era of state socialism through central political decision. After the changing of regime these were left alone without state aid. The author has argued that a new interpretation of their functions and the introduction of innovative organization forms may help them to be active in the 21st century (Lazic 2017). In order to test this a foundation named DRITO was created in Rovinj, Croatia to support the local colony.

Beyond economic development art colonies can provide help in community development as well. Their success can be strengthened by using the following principles (Phillips and Pittman 2009):

- A broader social support of arts - beyond local leaders the wider society should be involved in the decision making

- $\quad$ The mobilization of unexploited resources - local municipalities can provide help beyond financial support (e.g. preferential rent prices)

- The support of arts must be connected with the events of community development in order to make the community aware of the relevance of arts

- $\quad$ The optimal use of available resources - through the shared used of establishments and toils (workshops, gallery etc.)

- The use of supporting schemes adapted to the diverse demands of artists

\section{MATERIALS AND METHODS}

Cered, this border village in Nógrád county with a rapidly declining population (1215 inhabitants in 2019), has no special features, yet it bears all the characteristics of the "Hungarian countryside". That is exactly why the art colony, which started out as a personal initiative in 1996 and has since achieved international renown with strong ties to 
neighbouring Slovakia has been focusing on the local community, customs and of course contemporary Cered (Bujdoso et al. 2013).

The art colony is located in the western part of the village of Cered, on an area of about $5,000 \mathrm{~m} 2$, close to the Slovak border, and the Tarna stream, which flows a few hundred meters away, flows at the end of the garden. The methodology of the study was to prepare a case study based on empirical experiences gained in the participations of art colonies and the interviews conducted with local actors and inhabitants.

\section{RESULTS AND DISCUSSION}

Since art is primarily part of culture, first it is worth considering the socio-cultural effects of the Cered International Art Colony on the settlement. The significant mission of the art colony is a constant dialogue and social involvement with local society through the means of contemporary art, which is why the population of Cered encounters a new, higher-level culture from similarly peripheral, somewhat isolated local societies. The appearance of artists and art professionals from 23 countries representing different art genres in the settlement during the past period represents a special value and can provide openness to the local society. This is because local people find it difficult or impossible to meet similar impulses "on their own," the "import of art and culture" provides them this opportunity. The "Kor-Társ-Táj-Ház" itself (which also runs as the Museum House) and the institution of the Sculpture Park are constantly presented in the life of the locals, while visitors and tourists can see it as an attraction.

Among the Art Colony's effects on the development of Cered, it is definitely worth mentioning the support and maintenance of local traditions. This is especially important for the future of the settlement, as it provides a transfer for the next generation. This includes the possibility for appearance of local art groups (Cered Women's Choir, traditionalists, antique collectors) and the presence of rural hospitality, local gastronomy on the event (honey producers, cheese and brandy makers, fruit and vegetable producers, local and surrounding village catering) also provides an opportunity to earn an income.

The ambassador of the name of Cered is also the Cered International Art Colony, as one of the main elements of settlement marketing is that the art colony has participated in nearly sixty exhibitions in Hungarian and European museums and galleries with works made in Cered, promoting the settlement's name and values. It is also a meeting place for Hungarian and foreign artists, where Hungary, including Cered, is represented as a venue for international contemporary art life. The art colony is in active cooperation with other similar art colonies, universities and artist groups, where they can also get acquainted with the name of the settlement. Books, catalogs and publications completed over a quarter of a century can be found in large libraries on several continents.
The beneficial economic development effects of the Art Colony can also be seen in Cered. Thanks to the carefully preserved photo and documentary background in the archive (house purchases, renovations, development tenders, building developments), the intensive activity of 25 years in this field can be demonstrated relatively accurately. The primary aspect even today is the employment of local (professional) labor. The scale of the figures is remarkable in itself (but if we add that civil society was basically set up for art and art mediation purposes), this gives the art colony a special status not only in the village of Cered but also among other art colonies currently operating in the country.

Although the revenues of the Art Colony increase through the partners and sponsors, by returning them into financing the events, this is also realized in the settlement through its multiplier effect.

Direct revenues and indirect sources (local tax revenues) from the use of events, mainly local products and services (accommodation, trade, etc.), also contribute to the growth of the income of the local population.

This is boosted by the increase in the intensity of local tourism during the Art Colony. A good example of this is the open days after the creative period and the latter there is a great number of visitors in the art program of the Art Picnic Festival (classical and salon music, literary, theatrical and children's performances)

Other social actions related to the Art Colony, such as book distribution, image design for village entrepreneurs, etc. they appear primarily as latent positive economic effects (not expenditures), thus contributing to the formation of the economic attitude of the rural population.

The most beautiful form of this was the creation of the Log Theater, which is an open-air theater with nearly 200 seats, taking advantage of the territorial level difference and topography of the colony hosting the performing arts programs. In addition, the continuous expansion of the collections of the works of the participating artists, the placement of street furniture and space elements also strengthen the growth of the human environment.

\section{CONCLUSIONS}

To summarize the results of the case study, we can say that the source of the themes of the Art Colony is the isolation, peripheral position, integrity, marked visual, material environment and intellectual traditions of the settlement, i.e. the expression of the symbiosis of the natural and human environment. Thus, the effects of the colony on the (natural and human) environment are evident. In order to create the colony, mostly empty buildings and plots were purchased in the settlement, and within the five building complexes after several changes of function due to the expansion - the painting and graphic studio, gallery, workshop, sculpture workshop, Sculpture Park and outdoor creative sites are 
located, thus contributing to the improvement of the quality of the urban environment. A practical implication of the mentioned findings is that art would be a mediator between local residents, actors and developers.

\section{OPEN ACCESS STATEMENT}

This article has been published under a Creative Commons Attribution 4.0 international license that provides immediate open access to its content on the principle that making research freely available to the public supports a greater global exchange of knowledge.

\section{ACKNOWLEDGEMENTS}

We thank three unknown reviewers of this paper for their comments and suggestions that significantly improved this paper.

\section{REFERENCES}

Becker, H. S. (1982). Art Worlds. University of California Press, Berkeley

Beyers, W. and Lindahl, D. (1996). Lone eagles and high fliers in rural producer services. Rural Development Perspectives, 11(3), 2-10.

DOI: $\underline{10.22004 / \text { ag.econ.289750 }}$

Bille, T. and Schulze, G. G. (2011). Culture in Urban and Regional Development. In V. A. Ginsburgh and D. Throsby (Eds.), Handbook of The Economics of Art and Culture (pp. 1051-1099). Amsterdam: Elsevier.

Bourdieu, P. (1984). Distinction. A Social Critique of the Judgement of Taste. Cambridge: Harvard University Press.

Brennan-Horley, C. (2010). Multiple work sites and citywide networks: A topological approach to understanding creative work. Australian Geographer, 41(1), 39-56.

DOI: $\underline{10.1080 / 00049180903535550}$

Bujdosó, Z. (2004) The impact of the county border on the agglomeration area of cities: the example of Hajdú-Bihar county (in Hungarian). PhD Thesis, University of Debrecen. $221 \mathrm{p}$.

Bujdosó, Z., Dávid, L., Kovács, T., Remenyik, B., Zhomartova, Uakhitova (2013) Opportunities for the development of ecotourism with special regard to the East HungarianSlovakian border. Education and Science without Borders 4(1), 16-22.

Bujdosó, Z., Dávid, L., Varga, D., Pénzes, J., Gyurkó, Á., Zhapukov, A. (2015). Tourism development and crossborder cooperation in the Hungarian-Romanian border region. Geojournal of Tourism and Geosites, 16(2), 153163.
Csikszentmihalyi, M. (1999). Implications of a Systems Perspective for The Study of Creativity. In R. J. Sternberg (Ed.), Handbook of Creativity (pp. 313-335). New York: Cambridge University Press

Debroux, T. (2013). Inside and outside the city. An outline of the geography of visual artists in Brussels (19th-21st centuries), Brussels Studies 69, 1180.

DOI: $10.4000 /$ brussels. 1180

Działek, J., \& Murzyn-Kupisz, M. (2014). Young artists and the development of artistic quarters in Polish cities. Belgeo 2014(3) 1-30.

DOI: $10.4000 /$ belgeo.13012

Florida, R. (2002). The Rise of The Creative Class: And How It Is Transforming Work, Leisure, Community and Everyday Life. New York, Basic Books

Gaztambide-Fernández, R. (2008). The artist in society: Understandings, expectations, and curriculum implications. Curriculum Inquiry, 38(3), 233-265.

DOI: $10.1111 / \mathrm{j} .1467-873 X .2008 .00408 . \mathrm{x}$

Gkartzios, M. and Crawshaw, J. (2019). Researching rural housing: With an artist in residence. Sociologia Ruralis 59(4) 589-611.

DOI: $10.1111 /$ soru. 12224

Ingold, T. (2013). Making Anthropology, Archaeology, Art And Architecture. London, Uk: Routledge, 2013, 164 p.

Ilieș, D.C., Caciora, T., Herman, G.V., Ilieș, A., Ropa, M., Baias, Ș. (2020). Geohazards affecting cultural heritage monuments. A complex case study from Romania. GeoJournal of Tourism and Geosites, 31(3), 1103-1112.

Jeffri, J. (1988). Artists As Consumers. American Demographics 1988(4), 28-30.

Komives, T., \& Kiraly, Z. (2019). Cultural heritage - the first research campus in Hungary. Ecocycles, 5(2), 6-11. DOI: $10.19040 /$ ecocycles.v5i2.145

Landry, C. (2008). The Creative City. A Toolkit for Urban Innovations. London, Sterling, Va: Earthscan

Lazic, S. (2017). Artist Residency Programs in Rural Areas In Serbia: New Organizational Models. Belgrade, UNESCO Chair in Cultural Policy and Management, 90 p.

Liang, S. and Wang, Q. (2020). Cultural and creative industries and urban (re)development In China. Journal of Planning Literature, 35 (1) 54-70.

DOI: $\underline{10.1177 / 0885412219898290}$

Madanipour, A., Knierbein, S., \& Degros, A. (2014). A Moment Of Transformation. In A. Madanipour, S. Knierbein, \& A. Degros (Eds.), Public Space and the 
Challenges of Urban Transformation in Europe (pp. 1-8). New York and London: Routledge.

Markusen, A. (2006). Urban development and the politics of a creative class: Evidence from a study of artists. Environment and Planning A: Economy and Space 38(10) 19211940.

DOI: $\underline{10.1068 / \mathrm{a} 38179}$

Markusen, A. (2014). Creative cities: A 10-year research agenda. Journal of Urban Affairs, 36(2), 567-589.

DOI: $\underline{10.1111 / \text { juaf.12146 }}$

Markusen, Ann (2007). An arts-based state rural development policy. Journal of Regional Analysis and Policy 37(1), $1-3$.

DOI: $\underline{\text { 10.22004/ag.econ.132969 }}$

Matlovičová, K., Tirpáková, E., Mocák, P. (2019). City brand image: Semiotic perspective - a case study of Prague. Folia Geographica, 61(1), 120-142,

Mattingly, Paul (2019). An American Art Colony, Rowman \& Littlefield, 274 p.

Mátyás, Sz. (2015). Subjective sense of security - public opinion about public safety and the police (in Hungarian). Magyar Rendészet 2015/5. pp. 159-170.

Mcgranahan D. and Wojan T. (2007). Recasting the creative class to examine growth processes in rural and urban counties, Regional Studies, Vol. 41, 197-216.

\section{DOI: $\underline{10.1080 / 00343400600928285}$}

Meusburger, P. (2009). Milieus of creativity: The role of places, environments, and spatial contexts. In: Funke, J. and Wunder, E. (2009): Milieus of Creativity. An Interdisciplinary Approach to Spatiality of Creativity. Springer, pp 97153.

DOI: $\underline{10.1007 / 978-1-4020-9877-2 \_7}$

Phillips, R. and Pittman, R. (2009). An Introduction to Community Development. Routledge, 392 p.

Pickard, R. and Dambis, J. (2008). Integrated Management Tools in the Heritage of South-East Europe. Council of Europe. 283 p.

Rosenfeld, S. (2004). Crafting a New Rural Development Strategy. Economic Development America, Summer. pp. 11-13.

Törnqvist, G. (1983). Creativity and the Renewal of Regional Life. In: Buttimer, A. (Ed.): Creativity and Context. A Seminar Report. Gleerup, Lund, pp. 91-112.

Woods, M. (2015). Creative Ruralities. 'Creativity on the Edge' Symposium, Moore Institute, National University of Ireland Galway, June 2012

Zukin, S. (1989). Loft Living. Culture and Capital in Urban Change. New Brunswick: Rutgers University Press.

(C) 2021 by the author(s). This article is an open-access article distributed under the terms and conditions of the Creative Commons Attribution (CC BY) license (http://creativecommons.org/licenses/by/4.0/). 